


\title{
Documenting Loss Aversion using Evidence of Round Number Bias
}

\author{
Stephen Ross \\ Department of Economics \\ University of Connecticut \\ Storrs, CT 06269-1063 \\ stephen.1.ross@uconn.edu \\ (860) 486-3533 \\ Tingyu Zhou \\ Department of Risk Management/Insurance, Real Estate, and Legal Studies \\ Florida State University \\ Tallahassee, FL 32306 \\ tzhou@business.fsu.edu \\ (850) 644-0916
}

November 3, 2020

\begin{abstract}
Many studies document loss aversion in the housing market, where expected losses lead to higher sales prices. However, exposure to expected losses may correlate with unobservables that influence housing prices. Under the assumption that multiple psychological biases appear together, we estimate loss aversion by identifying sellers who appear psychologically biased by exhibiting focal point or round number bias in their choice of mortgage amount at purchase. Using both difference-in-differences and regression discontinuity approaches, we find evidence of loss aversion on sales prices based on a stronger correlation between loss and sales price for our subsample of sellers who exhibited round number bias, but our estimated effects are substantially smaller than the results that arise from directly estimating the effects of expected loss on the sales price. In addition, lumpy sellers are less likely to sell relative to the control group. We show that expected loss correlates strongly with predetermined mortgage, housing unit, and census tract attributes, but the interaction between a round mortgage amount and expected loss exhibits far fewer failures of balance. Further, the magnitude of the sample-wide relationship between expected loss and sales price is eroded substantially by the inclusion of balancing test controls, as well as by the inclusion of a running variable for the mortgage amount, while the magnitude of the relative estimates for the round mortgage amount subsample is quite stable. Evidence from an earlier experiement showing a positive relationship between reporting round numbers and loss aversioin provide supports for our identification strategy.
\end{abstract}

Keywords: loss aversion, anchoring, mortgage, behavioral bias, round number bias, focal point, house prices, sale likelihood 


\section{Introduction}

Loss aversion is a key phenomenon documented within behavioral economics and occurs when individuals place much more weight on nominal losses than on gains and/or may face a psychological cost associated with realizing these losses. Loss aversion in the housing market may be especially important due to the size of the housing market, the magnitude of any individual transaction, and the complexity of housing price dynamics. Genesove and Mayer (2001) established the standard reduced-form approach for studying the effects of loss aversion on the list price, sales price, and the likelihood of sale comparing the predicted sales price of a housing unit (based on observables and market circumstances) to the original purchase price. ${ }^{1}$ Virtually all later studies have followed this same approach, including, for example, studies by Anenberg (2011), Bokhari and Gelter (2011) and Bracke and Tenreyro (In Press) on housing list prices, sales prices and/or probability of sale, by Engelhardt (2003) on mobility, and by Ong et al. (2007) on mortgage default. $^{2}$

As noted by Genesove and Mayer (2001), the variable of interest, expected loss, includes both unobserved housing attributes and any premium paid or discount received relative to the market price at the time of purchase, which may lead to bias in the estimates of loss aversion if exposure to expected losses correlates with other factors that influence sales price. For example, houses that are of higher quality on factors not documented in a traditional assessors file may experience smaller declines in their market price during an economic downturn. Also, households with strong preferences for specific housing attributes may have fewer outside options when

\footnotetext{
${ }^{1}$ In behavioral economics, loss aversion can also be thought of as anchoring based on the purchase price. Other studies document anchoring based on housing prices in a buyers previous location (Lambson et al. 2004; Simonsohn 2006) and based on previous sales within the same government program (Arbel et al. 2014). In this study, we do not differentiate loss aversion from other forms of anchoring.

${ }^{2}$ In one rare exception, Anderson et al. (2020) estimates a structural model of loss aversion estimating the concavity of the relationship between sale prices and expected gains and losses. Some studies examine loss aversion in housing markets using a low stake, experimental framework, see for example Scott (2012) and Paraschiv and Chenavaz (2011).
} 
bargaining for a housing unit and so be more likely to pay a premium above the market price. These same sellers may also differ from other homeowners in their likelihood of changing jobs or facing financial distress during an economic downturn when housing prices are often depressed. ${ }^{3}$

In this paper, we address these concerns about bias in estimates of the housing sales price effect of nominal losses using a difference-in-differences approach by dividing households into those whose decisions are more likely to be affected by behavioral factors and those who may be more likely to make rational decisions in the housing market. Specifically, assuming that psychological biases tend to be found together, we divide households into those who exhibited evidence of focal point or round number bias when selecting their mortgage amount and those who did not. Previous studies document situations where decision makers have been found to be influenced by multiple psychological biases. For example, Fraser et al. (2015) find evidence that left digit bias is more pronounced in financial markets when stock trades involve losses, and Epper et al. (2011) show that in experiments, departures from linear probability weighting and nonexponential discounting also tend to found together. Finally, using data from a recent experiment (Karle et al., 2015), we show that individuals that reported round numbers when asked about past spending exhibit substantially higher loss aversion.

In this paper, we test for a relationship between the effect of expected losses and whether a seller exhibits focal point bias or a bias towards round numbers when selecting their purchase mortgage amount, i.e., amounts in multiples of $\$ 5,000$. We focus on the initial mortgage amount because sellers (in the first sale) have far less stake in the mortgage amount than, for example, the sales price, and lenders are typically focused on loan to value and income ratios, rather than the

\footnotetext{
${ }^{3}$ See Shen and Ross (2020) for evidence that the composition of owner-occupied housing on the market changes over both traditionally observable and unobservable housing attributes as the economy recovers from a downturn. Bayer et al. (2016) show that the composition of borrowers changes over the housing cycle.
} 
specific mortgage amount. Other factors that correlate with losses during a housing downturn, such as the increased risk of unemployment, contractions in credit markets, and changes in the return to unobserved housing attributes, will likely affect all sellers whether or not their decisions suffer from psychological bias, and these effects will be differenced out, at least partially, of our difference-in-differences estimates of loss aversion.

Several studies provide evidence that individuals who are sensitive to focal point bias differ from those who do not appear to respond to round numbers. Chava and Yao (2017) show that buyers who tend to purchase very similar priced houses with a lower left digit have lower credit scores, less income, and higher leverage. They also document that these buyers are less likely to refinance their mortgage when interest rates fall. ${ }^{4}$ Backus et al. (2019) examine the initial list price for eBay best offer negotiations documenting that sellers who list prices in multiples of $\$ 100$ are more likely to accept the initial offer and are less aggressive when making counteroffers. Wiltermuth et al. (2020) demonstrate that some homeowners will respond to a higher left digit in their own purchase price by later selecting a lower list price and selling for a lower final price, but show that left digit bias is malleable in that having an experienced real estate agent eliminates these left digit effects. ${ }^{5}$

Credit constraints also can be an important source of confounding variation because housing price declines that result in losses can also erode housing equity, reducing mobility and changing the bargaining position of sellers (Genosove and Mayer 1997; Chan 2001; Engelhardt

\footnotetext{
${ }^{4}$ Deng et al. (2003) document such heterogeneity in the context of mortgage prepayment and default a separation between those who "ruthlessly" pull the trigger on these options when they are "in the money" and those who fail to act rationally when making these decisions.

${ }^{5}$ Other examples of research on focal point bias include round numbers in housing sales prices (Pope et al., 2015), effects of the suggested donation amount in direct mail fundraising (Reiley and Samek, 2019), effects of list price on sales price of used cars (Lecetera et al., 2012; Busse, 2013), borrowers using round numbers when misreporting assets in mortgage applications (Garmaise, 2014), and the marketing effects of odd-numbered prices, e.g., 9-ending prices (Kashyap, 1995; Levy et al., 2011; Hall, 2015).
} 
2003; Bracke and Tenreyro In Press). ${ }^{6}$ Therefore, we define our sample of individuals who selected round numbers in the purchase mortgage amount, as well as our non-round number control group, excluding buyers who appear credit-constrained because they selected one of the key loan-to-value (LTV) thresholds that affect access to and the price of mortgage credit, e.g., $0.80,0.90,0.95,0.97$, and 1.00 or utilized subordinate debt, i.e., a second mortgage at origination. We do not include these observations in either our psychologically-biased or control group subsample since conditional on housing price the economic incentives to bring LTV down to a threshold may result in a rational buyer choosing a round mortgage amount or a psychologically biased buyer being forced into a non-round amount.

Using more than 500,000 single-family housing transactions in Connecticut from 1994 to 2017, we first show that there are unusually high probabilities of "lumpy mortgages", with the mortgage amounts ending with 5,000 or 10,000 without the targeting of critical LTV ratios. When borrowers decide how much to borrow, they potentially either calculate the loan amount rationally and precisely based on a desired downpayment, or just take a rough and close number ending with 5,000 or 10,000. In the former case, the loan amounts should be non-rounded numbers and are less likely to be lumpy. We interpret these lumpy buyers as buyers who may be more likely to suffer from behavioral biases when making other decisions within the housing market.

We then follow the analytical framework of Genesove and Mayer (2001) except that we interact a dummy for lumpy mortgage and a dummy for credit-constrained borrower with the expected loss and with all additional controls. We find that the estimated coefficient on the interaction of lumpy mortgage with expected loss implies that our behaviorally biased subsample

\footnotetext{
${ }^{6}$ Specifically, Bracke and Tenreyro (In Press) examine the relative importance of credit constraints and loss aversion by examining a subsample of cash only purchases. They find that loss aversion is relatively more important in affecting prices, while credit constraints are relatively more important in affecting selling propensities.
} 
sells their houses at a price that is higher by approximately 10 percent of the expected loss relative to the sales prices for our control sample given their expected loss. On the other hand, the loss aversion implied by examining the direct effect of expected loss for the control sample, i.e., the cross-sectional correlation between sales price and expected loss, implies price increases of about 40 percent of the expected loss.

Further, balancing tests suggest that expected loss is likely to be correlated with unobservables because it correlates strongly with a wide variety of mortgage, housing, and census tract attributes. As a result, the large effect of loss aversion among our control sample may be biased. On the other hand, the difference in the correlation between expected loss and these attributes between the behaviorally biased and control samples is modest relative to the direct balance test estimates and statistically insignificant for all of the mortgage and housing attributes. While the interaction of loss and lumpy mortgage fails balance on a few census tract attributes, the inclusion of the balancing test attributes leaves the estimate on expected loss interacted with lumpy mortgage unchanged, but erodes the direct effect of expected loss in the control group by half, consistent with upward bias from those previously omitted controls.

Our estmates for the control group are similar to those found by Annenberg (2010), who also applied a Genosove and Mayer (2001) style model to a broad sample of housing transactions. Annenberg (2010) estimates an effect size of approximately 0.36 using all repeat sales transactions in the San Francisco bay area, as compared to our control group estimates are 0.40 using repeat sales in Connecticut. Genosove and Mayer's (2001) estimates of price effects are substantially smaller, ranging between 0.03 and 0.18 likely due to a much more homogeneous sample of condominium sales in Boston, MA. Notably, the upper bound on Genosove and Mayer's (2001) estimates is quite close to our control group estimate of 0.20 after including detailed controls for 
housing, mortgage, and census tract attributes. Bracke and Tenreyro (In Press) also find more modest estimates of 0.25 for residential housing in England and Wales, but their sample is restricted to cash-only sales, again possibly leading to a substantially more homogeneous sample of borrowers. Zhou et al. (2020) also document a potential upward bias in estimates of the effect of loss aversion on sales prices based on bias in the composition of repeat sales transactions due to unobserved quality (Nowak and Smith, 2020; Shen and Ross, 2020).

Next, we follow Backus et al. (2019) and estimate a model similar to a regression discontinuity model except that the effect of treatment is estimated using only the observations right at the discontinuity or at the round mortgage amount, rather than observations to the right of the discontinuity. This allows us to compare the sales price of borrowers who experience a predicted loss and have a mortgage amount exactly at a round $\$ 5,000$ increment to borrowers who have nearly identical mortgage amounts, but whose mortgage amounts are not a round number. The magnitude of the interaction between expected loss and the lumpy mortgage dummy that captures the discontinuity is very similar to the traditional regression results reported above, but the estimate on expected loss for the control group is less than half of our baseline estimates (and about a $1 / 3^{\text {rd }}$ the size after adding balancing test controls) when the comparison is restricted sellers with similar initial mortgage amounts. The estimate of loss aversion based on the difference between the round number sample and non-round number control group is relatively stable to the use of a discontinuity-based identification strategy, while the control group estimate of loss aversion erodes substantially.

Our paper contributes to the extensive literature in anchoring and loss aversion first by providing convincing evidence of loss aversion using a new identification strategy that yields estimates that are relatively robust to the inclusion of controls for the mortgage, housing unit and 
neighborhood attributes. At the same time, we provide evidence that the application of the standard empirical approach when applied to broad samples of housing transactions may overstate the extent of loss aversion due to a correlation between the types of houses and sellers on the market and the business or housing market cycle. Our findings are consistent with the evidence of compositional changes in the housing market over the business cycle, as documented by Nowak and Smith (2020) and Shen and Ross (2020). Our paper is also related to the focal point bias literature providing additional evidence that behavioral phenomenon like focal point bias and loss aversion are likely to be found together (e.g., Fraser et al., 2015) and that individuals who exhibit psychological biases are different on average from those who do not (Backus et al., 2019; Chava and Yao, 2017).

\section{Experimental Evidence on Loss Aversion and Round Numbers}

Prior studies (e.g., Fraser et al. 2015, Epper et al. 2011) show that multiple psychological biases tend to found together. To provide evidence of a direct connection between loss aversion and the selection of round numbers, we test the relationship between reporting round numbers on a survey question and an estimate measures of loss aversion using data from an earlier experiment. Karle et al. (2015) study the effect of loss aversion on consumption using an experiment where they first ask individuals to report their preferences between two sandwiches and then randomize the prices of the two sandwiches so that some buyers face a loss involving a higher than expected price for the sandwich that they prefer. This experiment was conducted with University of Mannheim students in the fall of 2010. As part of this study, they had individuals make choices across a series of lotteries and sure pay-offs intended to measure loss aversion. They also separately estimate the continuous loss aversion parameter from Tversky and Kahneman's (1992) expontential utility function. To mitigate the effect of outliers, they also categorize the continuous 
measure by assigning individuals values between 1 to 4 capturing from "loss-seeking or neutral" to "strongly loss-averse." In addition, individuals were asked to report how much they typically spend on lunch in Euros when went out to buy lunch. We then create a variable that takes a value one if they report spending 5,10 or 15 Euros on lunch, and zero if they reported a non-round number for lunch expenditures. Approximately $21 \%$ of the sample reported typically spending 5 , 10 or 15 Euros on lunch with most of those individuals reporting 5 Euros. Following Karle et al. (2015), we drop individuals from the sample who gave inconsistent responses to the lottery questions that were used to assess loss aversion.

Table 1 presents the results of models that regress either the continuous measure of loss aversion (columns 1-3) or categorical measure (columns 4-6) on a dummy variable for whether the individual reported either 5, 10 or 15 Euros as what they typically spend on lunch. Columns (1) and (4) present the univariate regression, columns (2) and (5) present results adding standard controls for age, gender, income and number of semesters of university completed. The last two columns add an additional control for the self-report of the number of times the individual typically eats lunch out each week. All coefficient estimates on the round number dummy variable are statistically significant and sizable. The univariate models imply higher loss aversion for the round number subsample of 3.34 for the continuous measure or 0.49 standard deviations and 0.564 higher or 0.58 standard devations for the categorical measure. The addition of controls tends to erode the magnitude of the estimates, but they are still sizable ranging between 0.44 and 0.50 standard deviations. The subset of people who rounded when responding to a specific question clearly exhibited higher levels of loss aversion in an experiment that is entirely independent of our study. These results support our assumption that round number bias and loss aversion are likely found together. 


\section{Housing Sales Data and Sample Construction}

Our data contains 548,568 single-family residential transactions between January 1994 and December 2017 in 6 labor market areas (LMAs) across 169 towns in Connecticut. ${ }^{7}$ Data were collected by town halls monthly from 1994 onward. Our data contain property characteristics and mortgage information at the time of each sale. These timely records are important because many repeat sales studies (e.g., Anenberg, 2011) have property characteristics at the time of the second sale, but not the first sale. ${ }^{8}$ To avoid a common bias in repeat sales that arises from ignoring home improvements, we mitigate the threat of large unobservable quality changes between sales by deleting observations with changes in interior size between sales greater than $5 \%$, and directly control for any smaller changes in the housing unit by calculating predicted price based on the hedonic attributes at the time of the sale.

Our data also include the names of buyers and sellers, which allows us to use a fuzzy logic routine to ensure that the seller in the second transaction was the buyer in the first, as required to assign an expected loss to an individual seller. When there is more than one buyer or seller recorded, we ensure that at least one of the sellers/buyers in the second transaction was the buyer/seller in the first. ${ }^{9}$

The number of repeat sales tends to increase as the sample period increases. As a result, we require that the second sale occurs after 1999, a point at which the ratio of repeat sales to all

\footnotetext{
${ }^{7}$ Our initial sample includes over 1.5 million transactions. Following Clapp and Salavei (2010), our sample is restricted to single-family residential properties with 1) warranty deeds, 2) sale price over $\$ 50,000,3$ ) interior footage over 300sf and lot size between 1,500 sf and 10 acres, 4) more than three rooms and at least one bathroom, 5) structures built between 1901 and 2013, and 6) records of assessed building and land value.

${ }^{8}$ The towns are well distributed throughout the state, with good representation beyond the I-95, I-91 and I-84 corridors. Most importantly, there are many towns far from New York City, an international financial hub that has grown rapidly over the 20 years covered by the study. Connecticut is often described as two states: the wealthy, growing southwestern towns closest to the New York City and the remainder of the state.

${ }^{9}$ We use Matchit in STATA to perform the fuzzy match.
} 
sales has stabilized within our sample. Otherwise, the sample will substantially over-represent homes that sell rapidly. Our repeat sale sample includes 139,674 observations of second sales. The repeat subsample contains somewhat smaller, older houses than the single sale sample, as has been found in previous studies.

When analyzing sale probability, we assume that the relevant population of houses are those ever sold during our sample period, 1994-2017. We then construct a sample of 4,058,238 house-year observations based on 366,557 unique properties. This sample consists of 500,579 sale spells, which start from the year after the sale of a property and end in the year of next sale or the end of our sample period to account for censoring. For example, if a property sells for the first time in 2003, it cannot be included in the sample until 2004 as the loss and gain variables before 2003 is unknown. Similar to our analysis using sale prices, we begin the analysis of sale probability using sales that occur in 2000 or later to make our repeat sample more representative.

We classify the buyers of the first sale (i.e., the sellers of the second sale) into three groups: the lumpy mortgage group, the LTV-focused group, and the control group. The LTV-focused group includes likely credit-constrained buyers who either select one of the key LTV thresholds (i.e., an LTV ratio equals one of the critical ratios, e.g., $0.80,0.90,0.95,0.97$, and 1.00 , that suggest that the buyer targeted an important LTV ratio in the market) or took out a second mortgage at the time of purchase (subordinate debt). Appendix 2 summarizes details on identifying critical LTV ratios. The lumpy mortgage group includes buyers with the mortgage amounts ending with 5,000 or 10,000 excluding buyers in the LTV-focused group. The control group includes the rest of the sample after removing both the lumpy mortgage sample and the LTV-focused sample. By construction, the control group includes non-lumpy mortgage and non-financially-constraint buyers. 
In Table 2, we present the descriptive statistics separately for the expected loss and the expected gain subsamples. We find that sellers with an expected loss are more likely to be in our lumpy subsample. They also appear to be more financially constrained. The comparison of "months since purchase" reveals that loss is positively correlated with holding period between sales, consistent with loss aversion. In terms of housing attributes, houses in the loss sample are larger and older. Sellers with an expected loss have lower LTV ratios and are less likely to have a second mortgage at purchase. In terms of neighborhood attributes (measured using the 1990 census prior to our sample period), sellers with expected loss are in census blocks with higher percent of male, white, and college degree. Sellers with an expected loss also reside in neighborhoods with higher household income, lower poverty, and lower unemployment rate. These differences suggest that the sample may not be balanced between home sellers with expected losses and those with expected gains. We will present formal balancing tests after presenting our empirical model specifications.

\section{Empirical Models and Results}

We first model the log of sale price for seller $i$ of type $l$ in the quarter of purchase $s$, the quarter of sale $t$, and labor market area $c$, in a repeat sale framework following Genesove and Mayer (2001) as:

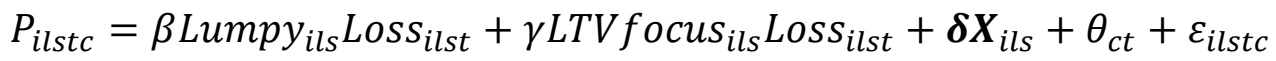

where lumpy $_{i l s}$ is the lumpy mortgage dummy which equals one for sellers whose first mortgage amount (taken from the time of purchase) ends with zero or five on thousands and without maximizing critical LTV thresholds, and zero otherwise; LTV focus ils $_{\text {is }}$ a dummy variable which equals one if buyers who select one of the key LTV thresholds (e.g., 0.80, 0.90, 0.95, 0.97, and 
1.00) or use second mortgages (i.e. subordinate debt) to maximize mortgage credit. Loss $s_{\text {ilst }}$ is expected loss and defined as the difference between the purchase price and the expected market value of the second sale truncated above zero. i.e., Loss $_{i l s t}=\left(\log _{\text {Price }} \text { ils }-\log \widehat{\operatorname{Prlc}} e_{l l t}\right)^{+} . \boldsymbol{X}_{i l s}$ includes lumpy $y_{i l s}$, LTV focus $_{i l s}$, Loss $i l s t$, and standard controls in the GM model, including the expected market value of the second sale, residual from the first stage hedonic model, months since purchase, and equity position at the second sale, as well as the interaction of lumpyils and LTV focus $_{i l s}$ with these additional controls. For equity position or current LTV based on expected sales price, we follow Anenberg (2011) and Abel (2018) and measure equity position using an estimated remaining mortgage balance amortized using the 30-year FHFA mortgage rate observed at purchase. $\theta_{c t}$ is the LMA-by-year-by-quarter fixed effects and absorbs time-varying local market conditions and seasonality. ${ }^{10}$ We cluster standard errors at LMA-quarter. ${ }^{11}$

Bokhari and Gelter (2011) find that sellers with an expected gain are willing to accept a lower price. For completeness, we next include the expected gain in equation (1) and run the following regression:

$$
\begin{aligned}
& P_{\text {ilstc }}=\beta^{l} \text { Lumpy }_{\text {ils }} \text { Loss }_{i l s t}+\gamma^{l} \text { LTVfocus }_{i l s} \text { Loss }_{i l s t}+\beta^{g} \text { Lumpy }_{\text {ils }} \text { Gain }_{\text {ilst }}+ \\
& \gamma^{g} \text { LTVfocus }_{\text {ils }} \text { Gain }_{\text {ilst }}+\boldsymbol{\delta} \boldsymbol{X}_{\text {ils }}+\theta_{c t}+\varepsilon_{\text {ilstc }}
\end{aligned}
$$

where Gain $_{\text {ilst }}$ is expected gain, measured using the difference between the purchase price and the expected market value of the second sale truncated below zero, i.e., Gain $_{\text {ilst }}=\left(\right.$ logPrice $_{i l s}-$ $\left.\log \widehat{\operatorname{PrlC}} e_{l l t}\right)^{-}$.

\footnotetext{
${ }^{10}$ Results are very similar using models with town-by-year fixed effects (Clapp and Zhou, 2019; Clapp et al., 2020). ${ }^{11}$ As there are only six LMA, we cluster at LMA-quarter level which is the same as our fixed effects (Bertrand, Duflo, and Mullainathan, 2004). Results clustered at the LMA level are highly similar.
} 
Before our analysis, we perform a battery of balancing tests. The objective is to examine whether the sample is balanced in terms of hedonic, mortgage, and census characteristics overall, and then whether it is balanced in terms of the differences between the lumpy mortgage and the unconstrained control group samples. We replace the outcome variable in equation (2) with a rich set of house, mortgage, and census characteristics. Columns (1) and (2) of Table 3 shows the coefficients and standard errors of expected loss. The results suggest that expected loss is correlated with most of the observed attributes. As a result, losses may also be correlated with unobservables which might bias both the loss effects estimated cross-sectionally for our control group and those results documented in the previous literature.

However, most of the coefficients for the interactions between loss and the lumpy mortgage dummy in columns (3) and (4) are smaller than the direct estimates on loss and statistically insignificant, suggesting at most modest evidence that attributes differ based on losses when we compare the lumpy mortgage sample to the control group. All the loss interaction coefficients for housing and mortgage attributes are statistically insignificant, and many of the interaction coefficients for census characteristics are statistically insignificant. However, we fail balance for few census characteristics such as racial composition, poverty, and housing vacancy. We partially mitigate this concern in later analyses when we include interactions between borrower type dummies (i.e., lumpy mortgage and LTV focused) and all the hedonic, mortgage, and census characteristics. The purpose of this follow-up analysis is to examine the stability of the loss aversion estimates to these controls both for the control group and for the difference between the lumpy mortgage group and the control group. We will also include borrower-type-by-tract fixed effects to control for tract unobservables since all of our balance failures on the interaction terms arise on tract attributes. 
Table 4 shows our baseline results. We start with a standard model used in Genesove and Mayer (2001) in column (1), i.e., equation (1) without the seller type interaction terms. The estimated coefficient for expected loss is large: a $10 \%$ expected loss is associated with $4 \%$ increase in sale price. In column (2), when we interact the lumpy mortgage dummy with expected loss and other controls, we find that those behaviorally biased individuals sell their houses at a price that is higher by about a 10 percent of the loss relative to the control group. In column (3), we add expected gain to the model from column (1). In column (4), we further add gain interactions with seller types to the model from column (2). We find that the magnitudes of both the coefficients on Loss for the control group and on Loss *Lumpy Mortgage are stable with the inclusion of controls for gains. The control variables have the expected sign and magnitude as in previous studies.

We show additional results in Table 5. Following the literature (e.g., Genesove and Mayer, 1997, 2001; Engelhardt, 2003; Anenberg, 2011), we use an alternative equity position calculated based only on current LTV when above the key threshold of 0.8 so that equity position is the minimum of zero and the estimated current LTV minus $0.8 .^{12}$ Panel A reproduces the main results from Table 4, and Panel B presents results with the alternative measure for equity position. The coefficient estimates for loss and loss interaction with lumpy mortgage are highly similar to the baseline results in Panel A and Table 4. The coefficients for truncated equity position (unreported) are positive, but statistically insignificant.

\footnotetext{
${ }^{12}$ Genesove and Mayer $(1997,2001)$ use Stein (1995)'s theory as motivation to look for reduced form relation between high LTV ratios, loss aversion, and prices. They find no statistically significant effect on selling prices for LTV values below 0.8 , consistent with the theory of a threshold effect.
} 
In Panel C of Table 5, we model sale hazard in a panel data framework. We write the hazard function for homeowner $i$ of type $l$ at year of purchase $s$, calendar year $t$, and labor market area $c$, as:

$$
\operatorname{Prob}(\text { Sale })_{i l s t c}=\text { Lumpy }_{i l s} \text { Loss }_{i l s t}+\gamma \text { LTV focus }_{i l s} \text { Loss }_{i l s t}+\boldsymbol{\delta} \boldsymbol{X}_{\text {ils }}+\theta_{c t}+\varepsilon_{i l s t c}
$$

The difference between equation (1) and (3) is that equation (1) models sale prices at the time of the second sale, while equation (3) models sale probability as a survival likelihood using panel data with every year following the initial purchase representing an observation until either a sale occurs or the end of the sample is reached. This means that the loss and gain variables vary over time $t$ within a sale spell as the market price varies over time. In our baseline controls in equation (3), we also control for time-varying equity position, again calculated using the estimated remaining mortgage balance divided by the expected sales price at time $t$. Instead of months since purchase, we control for years since purchase to fit our house-year panel. $\theta_{c t}$ is the LMA-by-year fixed effects. We cluster standard errors at LMA-year level.

We estimate equation (3) using a linear probability model to allow for a more exhaustive set of controls while maintaining computational tractability. The results in Panel C suggest a negative relationship between loss and sale hazard consistent with loss averse sellers leaving the property on the market longer in order to hold out for a higher sales price. Specifically, a $10 \%$ increase in loss is associated 0.7 to 1 basis point reduction in sale hazard among lumpy sellers, relative to the control group. The effect is economically significant because the yearly hazard is 3.66 basis point. In unreported results, there is no effect on the gain side as the gain coefficients and gain*lumpy interactions are insignificant. 
Given that we fail balance over some census characteristics, we examine whether our estimation results are stable when we include all the balance controls for the hedonic, mortgage, and census characteristics (see Table 3) and further interact the lumpy mortgage dummy, as well as the LTV focused dummy, with these variables. Comparing our baseline results reproduced in Panel A of Table 6 with the results adding balance control interactions in Panel B, we find the interaction coefficients for loss and lumpy mortgage are still statistically significant and of similar magnitude. However, the expected loss coefficients for the control group fall by almost $50 \%$ from 0.4 to 0.2 . The cross-sectionally estimated effects of expected loss are far more sensitive to controls for observables than the interactive effect arising from our lumpy mortgage subsample. However, comparing Panel C with Panel D for the probability of sale, we find the coefficients for Loss*Lumpy Mortgage becomes substantially more negative when we include balance control interactions, suggesting a potential positive bias created by omitted variables.

We further include seller-type-by-tract fixed effects in Table 7. We still observe significantly positive (negative) coefficients for Loss*Lumpy Mortgage in Panels A and B (C and D) using sale prices (sale probability) as the outcome variable. The magnitudes of the interaction coefficients reduce from 0.1 to 0.07 when we model sale prices. The use of tract fixed effects and their interactions controls for tract-level unobservables but also may exacerbate measurement errors in the expected loss experienced by the borrowers due to the limited number of repeat sales transactions within each census tract. The estimates for the probability of sale remain stable at 0.01 with the inclusion of tract by seller type fixed effects.

We next follow Backus et al. (2019) and estimate a model similar to a regression discontinuity design (RDD) model. This differs from the traditional RDD design because the effect of treatment is estimated using only the observations at exactly the discontinuity, rather than those 
to the right of the discontinuity. The idea is to compare the sale prices of a seller who experiences an expected loss and has a mortgage amount exactly at a round number with a seller who has a similar mortgage amount but on either side of this round number. We take mortgage multiples of $\$ 5,000$ to be the round number thresholds and define the operator $\operatorname{round}(x, y)$ to be the value of $x$ rounded to the nearest positive multiple of $y$. Essentially, we created a stacked discontinuity sample with a $\$ 2,500$ bandwidth on either side by defining normalized mortgage amounts, Run, as

$$
\text { Run = mortgage amounts }- \text { round(mortgage amounts, thresholds). }
$$

We define an indicator variable Above for Run greater than zero, and our lumpy mortgage dummy is one when Run=0. We include Run, Above, loss, loss*lumpy mortgage, loss*Run, and loss *Above in equations (1) and (2). The variable Run represents the running variable, and the interaction with loss allows the slope of the running variable to vary on either side of the discontinuity. We also include similar interactions for LTV focused dummy. As noted above, we use a bandwidth of $\$ 2,500$ around each round number so that the stacked samples do not overlap. We also include fixed effects for every round number and the observations within the bandwidth of that number so that a unique fixed effect represents each stacked subsample of data.

These results are shown in Table 8 . Panel A presents the baseline discontinuity results, Panel B adds balancing test controls and their interaction with seller type especially lumpy mortgage, and Panel $\mathrm{C}$ adds census tract by seller type fixed effects. Column (1) presents results for a model that only includes expected loss, and column (2) adds the controls for expected gain. In panel A, we find that the estimates on expected loss for the control group have fallen by more than half to between 0.15 and 0.18 with the inclusion of the mortgage amount bin fixed effects, but that the discontinuity estimate at 0.10 is basically the same as our baseline estimate from the simple difference-in-differences regression. As before, adding controls for all of the balancing test 
variables and their interaction with seller type or adding census tract by seller type fixed effects has minimal impact on the discontinuity estimate with estimates ranging between 0.11 and 0.12 . However, the addition of these controls further reduces the estimates for the control group to between 0.11 and 0.15 , between 25 and 40 percent of the initial control group estimate in Table 4 and well within the much smaller range of estimated effects found by Genosove and Mayer (1997) in condominium study.

Next, as flippers may be more likely to invest or renovate before reselling, improving the unobservables of the housing unit, one might be concerned that observed price appreciation may be likely due to such improvements rather than loss aversion in this subsample. Therefore, we examine whether our results are affected by the presence of flippers. We follow Bayer et al. (2020) and use the names of the buyer and seller to identify flippers as individuals engaged in the buying and selling at least two different properties while holding them for less than two years. Bayer et al. (2020) also identify flippers using a second home method where the buyer is observed to hold the second property and the additional property is sold within two years. The method we used here is more conservative because the individual must conduct multiple flips in our sample period while the second home method does not require contemporaneous overlap in property holdings. We find a similar pattern of the percentage of flipper-involved transactions over our sample period (unreported) as in Bayer et al. (2020), although we observe an overall smaller proportion of flippers because we only focus on single-family housing and Connecticut is less subject to speculative activities compared to Los Angeles. In Table 9, we conclude that our results are robust to dropping sales where either the buyer, the seller, or a combination of buyer and seller were identified as flippers. 
Further, Ben-David and Hirshleifer (2012) suggest that loss aversion is stronger for short holding periods when the purchase price is likely to be most salient as a reference point. We classify our sample into two sub-samples: months since purchase (year since purchase) greater or below median in Panels A and B (C and D) of Table 10. Similar to Ben-David and Hirshleifer (2012), we find that the expected loss effect for our lumpy mortgage sample relative to the control group is stronger for a short holding period with the magnitude of the effect doubling for our short holding period subsample. Similarly, we find larger effects of expected loss on the likelihood of sale for the short holding period subsample, again consistent with sellers leaving the property on the market longer in order to obtain a higher sales price. On the other hand, the cross-sectional effects of expected loss on sales price as indicated by the estimates for the control group do not vary with the holding period.

\section{Conclusions}

Based on the presumption that psychological biases in economic decisions are often found together, we apply a difference-in-differences approach to studying loss aversion by dividing sellers into those whose mortgage amounts at purchase were in multiples of 5,000 or 10,000 dollars and those who may be more likely to make rational decisions in the housing market, omitting apparently credit-constrained borrowers at critical LTV thresholds or who use subordinate debt. We first provide suggestive evidence of this presumption demonstrating that experimental measures of loss aversion are higher for a subsample that reported round numbers on a question about their outside experiences. Our balance test results suggest that expected loss correlates with a wide array of variables that could bias the cross-sectional relationship between expected loss and sales price, and the magnitude of the estimates are eroded by half with the addition of the balancing test controls. However, comparing seller who had round number mortgages with our control group, 
our interactive balancing tests suggest no failures on the mortgage or housing attributes and substantially fewer failures over census tract attributes. Further, the addition of the controls has no impact on the effect of expected loss on sales price for our lumpy mortgage sample as measured relative to the control group.

By dividing sellers into three groups (lumpy mortgage, LTV focused, and the control group), we find that lumpy sellers sell their houses at a price that is higher by about 10 percent of the expected loss relative to the sales prices for the control group. With a 10 -percent increase in expected loss, lumpy sellers are also about 1 basis point less likely to sell relative to the control group. Our results are robust to alternative measures of financial constraints, to the inclusion of a rich sets of controls of house, mortgage, and demographic characteristics, to inclusion of tract fixed effects, as well as to an alternative discontinuity based model exploring the differences between sellers with a mortgage amount exactly at the round numbers to those who have similar mortgage amount but not at a round number. While we find convincing evidence of loss aversion, the level of loss aversion implied by our analysis is substantially smaller than the levels identified in studies that directly estimate the effects of expected loss on sales prices in a broad sample of housing transactions.

\section{References:}

Anderson, S., Badarinza, C., Liu, L., Marx, J., Ramadorai, T. 2020. Reference Dependence in the Housing Market. SSRN Working Paper.

Anderson, E., Jaimovich, N., Simester, D., 2015. Price Stickiness: Empirical Evidence of the Menu Cost Channel. The Review of Economics and Statistics 97, 813-826.

Anenberg, E., 2011. Loss aversion, equity constraints and seller behavior in the real estate market. Regional Science and Urban Economics 41, 67-76. 
Arbel, Y., Ben-Shahar, D., Gabriel, S., 2014. Anchoring and housing choice: Results of a natural policy experiment. Regional Science and Urban Economics 49, 68-83.

Backus, M., Blake, T., Tadelis, S., 2018. On the Empirical Content of Cheap-Talk Signaling: An Application to Bargaining. Journal of Political Economy 127, 1599-1628.

Bardsley, N., Mehta, J., Starmer, C., Sugden, R., 2010. Explaining Focal Points: Cognitive Hierarchy Theory versus Team Reasoning. The Economic Journal 120, 40-79.

Bayer, P., Ferreira, F., Ross, S.L. 2016. The Vulnerability of Minority Homeowners in the Housing Boom and Bust. American Economic Journal: Economic Policy 8, 1-27.

Ben-David, I., Hirshleifer, D., 2012. Are Investors Really Reluctant to Realize Their Losses? Trading Responses to Past Returns and the Disposition Effect. Review of Financial Studies 25, 2485-2532.

Bertrand, M., Duflo, E., Mullainathan, S., 2004. How Much Should We Trust Differences-InDifferences Estimates? The Quarterly Journal of Economics 119, 249-275.

Bokhari, S., Geltner, D., 2011. Loss Aversion and Anchoring in Commercial Real Estate Pricing: Empirical Evidence and Price Index Implications. Real Estate Economics 39, 635-670.

Bracke, P., Tenreyro, S. In Press. History Dependence in the Housing Market. American Economics Journal: Macroeconomics.

Busse, M.R., Knittel, C.R., Zettelmeyer, F., 2013. Are consumers myopic? Evidence from new and used car purchases. American Economic Review 103, 220-256.

Busse, M.R., Lacetera, N., Pope, D.G., Silva-Risso, J., Sydnor, J.R., 2013. Estimating the effect of salience in wholesale and retail car markets. American Economic Review 103, 575579.

Chan, S. 2001. Spatial lock-in: Do falling house prices constrain residential mobility? Journal of Urban Economics 49(3), 567 - 586. 
Chava, S., Yao, V.W., 2017. Cognitive Reference Points, the Left-Digit Effect, and Clustering in Housing Markets. Working Paper. Georgia Institute of Technology and Georgia State University.

Clapp, J.M., Salavei, K., 2010. Hedonic pricing with redevelopment options: A new approach to estimating depreciation effects. Journal of Urban Economics 67, 362-377.

Engelhardt, G. V., 2003. Nominal loss aversion, housing equity constraints, and household mobility: Evidence from the United States. Journal of Urban Economics 53, 171-195.

Epper, T., Fehr-Duda, H., Bruhin, A. 2011. Viewing the future through a warped lens: Why uncertainty generates hyperbolic discounting. Journal of Risk and Uncertainty 43: 169203.

Fraser-Mackenzie, P., Sung M., Johnson, J.E.V. 2015. The prospect of a perfect ending: Loss aversion and round-number bias. Organization Behavior and Human Decision Processes $131,67-80$.

Genesove, D., Mayer, C., 2001. Loss Aversion and Seller Behavior: Evidence from the Housing Market. The Quarterly Journal of Economics 116, 1233-1260.

Hall, S., 2015. Odd Prices at Retail Gasoline Stations: Focal Point Pricing and Tacit Collusion. Journal of Economics and Management Strategy 24, 664-685.

Karle, H., Kirchsteiger, G., Peitz, M. 2015. Loss Aversion and Consumption Choice: Theory and Experimental Evidence. American Economic Journal: Microeconomics 7(2): 101-120.

Kashyap, A.K., 1995. Sticky Prices: New Evidence from Retail Catalogs. The Quarterly Journal of Economics 110, 245-274.

Lacetera, N., Pope, D.G., Sydnor, J.R., 2012. Heuristic thinking and limited attention in the car market. American Economic Review 102, 2206-2236. 
Lambson, V.E., McQueen, G.R., Slade, B.A., 2004. Do Out-of-State Buyers Pay More for Real Estate? An Examination of Anchoring-Induced Bias and Search Costs. Real Estate Economics 32, 85-126.

Levy, D., Lee, D., Chen, H. (Allan), Kauffman, R.J., Bergen, M., 2011. Price Points and Price Rigidity. The Review of Economics and Statistics 93, 1417-1431.

Mehta, J., Starmer, C., Sugden, R., 1994. The Nature of Salience: An Experimental Investigation of Pure Coordination Games. American Economic Review 84, 658-673.

Nowak, A., Smith, P. 2020. Quality-Adjusted House Price Indexes. American Economic Review: Insights 2, 339-356.

Ong, S.E., Sing, T.F., Teo, A.H.L., 2007. Delinquency and Default in Arms: The Effects of Protected Equity and Loss Aversion. The Journal of Real Estate Finance and Economics $35,253-280$.

Pope, D.G., Pope, J.C., Sydnor, J.R., 2015. Focal points and bargaining in housing markets. Games and Economic Behavior 93, 89-107.

Reiley, D., Samek, A., 2019. Round Giving: A Field Experiment on Suggested Donation Amounts in Public-Television Fundraising. Economic Inquiry 57, 876-889.

Shen, L., Ross, S., 2020. Information Value of Property Description: A Machine Learning Approach. Working Paper. University of Connecticut.

Simonsohn, U., 2006. New Yorkers Commute More Everywhere: Contrast Effects in the Field. Review of Economics \& Statistics 88, 1-9.

Tversky, A., Kahneman, D. 1992. Advances in Prospect Theory: Cumulative Representation of Uncertainty. Journal of Risk and Uncertainty 5 (4): 297-323. 
Wiltermuth, S.S., Gubler, T., Pierce, L., 2020. Anchoring on Historical Reference Points: How Round Number Prices from the Past Shape Future Negotiation Outcomes. Working Paper. University of Southern California, Brigham Young University, and Washington University in St. Louis.

Zhou, T, Clapp, J., Lu-Andrews, R. 2020. Do Sellers with Expected Losses Obtain a Premium Price? Really? Working Paper. Florida State University. 
Table 1: Loss Aversion and Self-Reported Round Numbers

\begin{tabular}{lllllll}
\hline & \multicolumn{3}{c}{$\begin{array}{c}\text { Loss Aversion } \\
\text { (Continuous Measure) }\end{array}$} & \multicolumn{3}{c}{$\begin{array}{c}\text { Loss Aversion } \\
\text { (Categorical Measure) }\end{array}$} \\
\hline Rounded Reporting & $3.336^{* *}$ & $3.433^{* *}$ & $3.021^{*}$ & $0.564^{* * *}$ & $0.471^{* *}$ & $0.427^{*}$ \\
& $(1.480)$ & $(1.614)$ & $(1.618)$ & $(0.211)$ & $(0.226)$ & $(0.228)$ \\
Age & & -0.092 & -0.102 & & 0.001 & -0.000 \\
& & $(0.159)$ & $(0.158)$ & & $(0.022)$ & $(0.022)$ \\
Gender (Male=1) & & 0.941 & 1.211 & & -0.226 & -0.197 \\
Semester & & $(1.287)$ & $(1.286)$ & & $(0.180)$ & $(0.181)$ \\
& & -0.009 & 0.015 & & -0.011 & -0.008 \\
Work Income (log) & & $(0.072)$ & $(0.072)$ & & $(0.010)$ & $(0.010)$ \\
& & -0.081 & -0.093 & & 0.025 & 0.024 \\
Number of Lunches Out per Week & & $(0.234)$ & $(0.233)$ & & $(0.033)$ & $(0.033)$ \\
Constant & & & $-0.798^{*}$ & & -0.084 \\
& $3.242^{* * *}$ & 5.290 & $7.267 *$ & $1.590^{* * *}$ & $1.672 * * *$ & $1.881^{* * *}$ \\
R-squared & $(0.673)$ & $(3.673)$ & $(3.820)$ & $(0.096)$ & $(0.515)$ & $(0.538)$ \\
Observations & & & & & & \\
\hline
\end{tabular}

Notes. This table shows results from regressions of loss aversion on rounded reporting dummy and control variables using the experimental data in Karle et al. (2015). Loss aversion (continuous measure) in columns (1) through (3) is estimated from an experiment of choices between lotteries and sure payment. To mitigate the influence of outliers, Karle et al. (2015) categorize the continuous measure into four numeric categories ranging from from " 1 - lossseeking or neutral" to "4 - strong loss-averse" that are used in columns (4) through (6). 
Table 2: Summary Statistics

\begin{tabular}{|c|c|c|c|c|}
\hline & \multicolumn{2}{|l|}{ Loss $>0$} & \multicolumn{2}{|l|}{ Loss $<0$} \\
\hline & Mean & Std Dev & Mean & Std Dev \\
\hline & $(1)$ & $(2)$ & (3) & (4) \\
\hline Log of Sale Price & 12.77 & 0.81 & 12.43 & 0.67 \\
\hline Dummy Lumpy Mortgage & 0.21 & 0.41 & 0.15 & 0.36 \\
\hline Dummy LTV Focused & 0.47 & 0.50 & 0.44 & 0.50 \\
\hline Loss & 0.32 & 0.28 & 0.00 & 0.00 \\
\hline Gain & 0.00 & 0.00 & 0.46 & 0.37 \\
\hline Market Price (log) & 12.49 & 0.58 & 12.52 & 0.59 \\
\hline 1st Residual & 0.28 & 0.34 & -0.22 & 0.41 \\
\hline Equity Position (LTV) & 0.69 & 0.34 & 0.56 & 0.39 \\
\hline Equity Position (LTV Truncated) & 0.07 & 0.14 & 0.05 & 0.21 \\
\hline Months since the Previous Sale & 68.27 & 43.75 & 64.83 & 55.09 \\
\hline \multicolumn{5}{|l|}{ Hedonic Characteristics } \\
\hline Interior Size (sf.) & 1,922 & 1,005 & 1,863 & 990 \\
\hline Lot Size (sf.) & 30,965 & 41,555 & 29,293 & 41,125 \\
\hline 2-3 bathrooms & 0.51 & 0.50 & 0.49 & 0.50 \\
\hline$>3$ bathrooms & 0.10 & 0.30 & 0.09 & 0.29 \\
\hline Age & 57.77 & 32.00 & 55.94 & 31.62 \\
\hline \multicolumn{5}{|l|}{ Mortgage Attributes } \\
\hline Mortgage Amount (First Mortgage, log) & 12.52 & 0.63 & 11.95 & 0.61 \\
\hline Combined Mortgage Amount (log) & 12.52 & 0.63 & 11.96 & 0.61 \\
\hline Loan to Value Ratio & 0.70 & 0.53 & 0.73 & 0.96 \\
\hline Combined Loan to Value Ratio & 0.70 & 0.53 & 0.73 & 0.96 \\
\hline Presence of Second Mortgage & 0.01 & 0.07 & 0.03 & 0.18 \\
\hline \multicolumn{5}{|l|}{ Census block characteristics (Census 1990) } \\
\hline Percent Female & 0.52 & 0.02 & 0.52 & 0.02 \\
\hline Percent white & 0.96 & 0.07 & 0.92 & 0.15 \\
\hline Median Household income & 77,744 & 32,108 & 65,353 & 26,143 \\
\hline Percent with college education & 0.37 & 0.18 & 0.28 & 0.16 \\
\hline Percent households with kids & 0.34 & 0.09 & 0.35 & 0.09 \\
\hline Average household size & 2.76 & 4.35 & 2.75 & 2.60 \\
\hline Percent below poverty & 0.02 & 0.03 & 0.04 & 0.07 \\
\hline Percent of owner-occupied housing with mortgage & 0.69 & 0.13 & 0.68 & 0.15 \\
\hline Unemployment rate & 0.04 & 0.03 & 0.05 & 0.04 \\
\hline Vacancy rate & 0.06 & 0.07 & 0.05 & 0.05 \\
\hline Median value of owner-occupied housing & 302,372 & 138,101 & 243,731 & 105,497 \\
\hline Percent of 65 and over & 0.14 & 0.07 & 0.14 & 0.07 \\
\hline
\end{tabular}

Notes. This table shows means and standard deviations for repeat-sale transactions with expected loss and expected gain. 
Table 3: Balance Tests

\begin{tabular}{|c|c|c|c|c|}
\hline & \multicolumn{2}{|l|}{ Loss } & \multicolumn{2}{|c|}{ Loss*Lumpy } \\
\hline & Parameter & SE & Parameter & SE \\
\hline & $(1)$ & $(2)$ & (3) & (4) \\
\hline \multicolumn{5}{|l|}{ Hedonic Characteristics } \\
\hline Interior Size & $200.839 *$ & $(21.21)$ & -26.137 & $(19.648)$ \\
\hline Lot Size & 8332.194 & $(1460.822)$ & -2068.738 & $(1881.025)$ \\
\hline Number of bathrooms & $0.145 * * *$ & $(0.020)$ & 0.019 & $(0.024)$ \\
\hline Number of bedrooms & $0.451 * *$ & $(0.039)$ & -0.062 & $(0.028)$ \\
\hline Age & $0.557 * * *$ & $(0.028)$ & -0.043 & $(-0.58)$ \\
\hline \multicolumn{5}{|l|}{ Mortgage Attributes } \\
\hline Mortgage Amount (First Mortgage) & $0.367 * * *$ & $(0.021)$ & 0.010 & $(0.022)$ \\
\hline Combined Mortgage Amount & $0.371 * * *$ & $(0.021)$ & 0.009 & $(0.022)$ \\
\hline Loan to Value Ratio (First Mortgage) & $-0.360 * * *$ & $(0.024)$ & 0.131 & $(0.078)$ \\
\hline Combined Loan to Value Ratio & $-0.357 * * *$ & $(0.024)$ & 0.130 & $(0.078)$ \\
\hline \multicolumn{5}{|l|}{ Census block characteristics (Census 1990) } \\
\hline Percent Female & $0.003 * * *$ & $(0.001)$ & -0.001 & $(0.001)$ \\
\hline Percent black & $0.035 * *$ & $(0.003)$ & $-0.017 * * *$ & $(0.003)$ \\
\hline Percent white & $-0.057 * *$ & $(0.005)$ & $0.024 * * *$ & $(0.003)$ \\
\hline Log Median Household income & $0.039 * * *$ & $(0.015)$ & -0.015 & $(0.014)$ \\
\hline Percent with college education & $0.090 * * *$ & $(0.004)$ & -0.000 & $(0.006)$ \\
\hline Average household size & $-0.013 * * *$ & $(0.003)$ & -0.002 & $(0.004)$ \\
\hline Percent below poverty & $0.025 * * *$ & $(0.004)$ & $-0.008 * * *$ & $(0.002)$ \\
\hline Percent of owner-occupants w/ mortgage & -0.005 & $(0.004)$ & -0.003 & $(0.004)$ \\
\hline Unemployment rate & $0.007 * * *$ & $(0.001)$ & -0.002 & $(0.001)$ \\
\hline Vacancy rate & $0.044 * * *$ & $(0.004)$ & $-0.014 * * *$ & $(0.003)$ \\
\hline Median value of owner-occupied housing & $0.103 * * *$ & $(0.017)$ & 0.011 & $(0.018)$ \\
\hline Percent of 65 and over & 0.000 & $(0.002)$ & 0.002 & $(0.002)$ \\
\hline
\end{tabular}


Notes. This table summarizes results from regressions of observable hedonic, mortgage, and census characteristics on loss, loss*lumpy mortgage dummy, control variables and a vector of labor-market-area-by-quarter fixed effects in equation (2). Models are estimated using OLS with errors clustered by labor market area-by-quarter. 
Table 4: Baseline Results

\begin{tabular}{|c|c|c|c|c|}
\hline & G\&M & Lumpy & w/ Gains & Lumpy w/ Gains \\
\hline & $(1)$ & $(2)$ & (3) & $(4)$ \\
\hline \multirow[t]{2}{*}{ Loss } & $0.402 * * *$ & $0.388 * * *$ & $0.392 * * *$ & $0.398 * * *$ \\
\hline & $(0.011)$ & $(0.017)$ & $(0.012)$ & $(0.018)$ \\
\hline \multirow[t]{2}{*}{ Loss*Lumpy Mortgage } & & $0.100 * * *$ & & $0.102 * * *$ \\
\hline & & $(0.020)$ & & $(0.020)$ \\
\hline \multirow[t]{2}{*}{ Loss*LTV Focused } & & $0.071 * * *$ & & $0.122 * * *$ \\
\hline & & $(0.021)$ & & $(0.022)$ \\
\hline \multirow[t]{2}{*}{ Gain } & & & $0.028 * *$ & 0.006 \\
\hline & & & $(0.012)$ & $(0.013)$ \\
\hline \multirow[t]{2}{*}{ Gain*Lumpy Mortgage } & & & & $-0.035 * *$ \\
\hline & & & & $(0.017)$ \\
\hline \multirow[t]{2}{*}{ Gain*LTV Focused } & & & & $-0.172 * * *$ \\
\hline & & & & $(0.017)$ \\
\hline \multirow[t]{2}{*}{ Market Price } & $0.900 * * *$ & $0.901 * * *$ & $0.897 * * *$ & $0.901 * * *$ \\
\hline & $(0.004)$ & $(0.005)$ & $(0.004)$ & $(0.005)$ \\
\hline \multirow[t]{2}{*}{ Market Price*Lumpy Mortgage } & & $-0.010 *$ & & -0.006 \\
\hline & & $(0.005)$ & & $(0.005)$ \\
\hline \multirow[t]{2}{*}{ Market Price*LTV Focused } & & 0.006 & & $0.016 * * *$ \\
\hline & & $(0.005)$ & & $(0.006)$ \\
\hline \multirow[t]{2}{*}{ 1st Residual } & $0.500 * * *$ & $0.423 * * *$ & $0.519 * * *$ & $0.423 * * *$ \\
\hline & $(0.008)$ & $(0.009)$ & $(0.007)$ & $(0.010)$ \\
\hline \multirow[t]{2}{*}{ 1st Residual*Lumpy Mortgage } & & $0.039 * * *$ & & 0.020 \\
\hline & & $(0.012)$ & & $(0.015)$ \\
\hline \multirow[t]{2}{*}{ 1st Residual*LTV Focused } & & $0.223 * * *$ & & $0.104 * * *$ \\
\hline & & $(0.009)$ & & $(0.016)$ \\
\hline \multirow[t]{2}{*}{ Months } & $-0.001 * * *$ & $-0.001 * * *$ & $-0.001 * * *$ & $-0.001 * * *$ \\
\hline & $(0.000)$ & $(0.000)$ & $(0.000)$ & $(0.000)$ \\
\hline \multirow[t]{2}{*}{ Months*Lumpy Mortgage } & & $0.001 * * *$ & & $0.001 * * *$ \\
\hline & & $(0.000)$ & & $(0.000)$ \\
\hline \multirow[t]{2}{*}{ Months*LTV Focused } & & -0.000 & & -0.000 \\
\hline & & $(0.000)$ & & $(0.000)$ \\
\hline \multirow[t]{2}{*}{ Equity Position } & $-0.008 * * *$ & $-0.024 * *$ & $-0.008 * * *$ & $-0.024 * *$ \\
\hline & $(0.003)$ & $(0.010)$ & $(0.003)$ & $(0.010)$ \\
\hline \multirow[t]{2}{*}{ Equity Position*Lumpy Mortgage } & & $0.036 * * *$ & & $0.036 * * *$ \\
\hline & & $(0.011)$ & & $(0.011)$ \\
\hline \multirow[t]{2}{*}{ Equity Position*LTV Focused } & & $-0.415 * * *$ & & $-0.547 * * *$ \\
\hline & & $(0.021)$ & & $(0.029)$ \\
\hline \multirow[t]{2}{*}{ Lumpy Mortgage } & $0.022 * * *$ & 0.085 & $0.023 * * *$ & 0.044 \\
\hline & $(0.003)$ & $(0.063)$ & $(0.003)$ & $(0.065)$ \\
\hline \multirow[t]{2}{*}{ LTV Focused } & $-0.089 * * *$ & $0.163 * *$ & $-0.087 * * *$ & $0.181 * *$ \\
\hline & $(0.003)$ & $(0.070)$ & $(0.003)$ & $(0.074)$ \\
\hline \multirow[t]{2}{*}{ Constant } & $1.369 * * *$ & $1.374 * * *$ & $1.400 * * *$ & $1.363 * * *$ \\
\hline & $(0.054)$ & $(0.060)$ & $(0.050)$ & $(0.061)$ \\
\hline LMA-Year-Quarter FE & Yes & Yes & Yes & Yes \\
\hline R-squared & 0.810 & 0.819 & 0.810 & 0.820 \\
\hline Observations & 139,674 & 139,674 & 139,674 & 139,674 \\
\hline
\end{tabular}

Notes. This table summarizes results from regressions of sale price on loss, loss*lumpy mortgage and controls.

Standard errors are clustered at the labor-market-area-by-quarter level. Column (1) follows a standard model used in Genesove and Mayer (2001). Column (2) adds interactions between loss and borrower types (lumpy mortgage and LTV focused). Column (3) adds expected gain to column (1). Column (4) adds gain interactions to column (2). 
Table 5: Additional Results

\begin{tabular}{lllll}
\hline & G\&M & Lumpy & w/ Gains & Lumpy w/ Gains \\
\hline A. Baseline & $(1)$ & $(2)$ & $(3)$ & $(4)$ \\
Loss & & & & \\
& $0.402^{* * *}$ & $0.388^{* * *}$ & $0.392^{* * *}$ & $0.398^{* * *}$ \\
Loss*Lumpy Mortgage & $(0.011)$ & $(0.017)$ & $(0.012)$ & $(0.018)$ \\
& & $0.100^{* * *}$ & & $0.102^{* * *}$ \\
& & $(0.020)$ & & $(0.020)$ \\
B. Alternative Equity Position & & & & \\
Loss & $0.401^{* * *}$ & $0.403 * * *$ & $0.391 * * *$ & $0.408^{* * *}$ \\
& $(0.011)$ & $(0.017)$ & $(0.012)$ & $(0.018)$ \\
Loss*Lumpy Mortgage & & $0.102^{* * *}$ & & $0.103^{* * *}$ \\
& & $(0.020)$ & & $(0.020)$ \\
C. Probability of Second Sale & & & & \\
Loss & & & & $-0.017 * *$ \\
Loss*Lumpy Mortgage & -0.005 & $-0.005^{*}$ & $-0.015^{* *}$ & $(0.007)$ \\
& $(0.003)$ & $(0.003)$ & $(0.006)$ & $-0.007 * * *$ \\
\hline
\end{tabular}

Notes. Panels A and B (Panel C) show results from regressions of sale price (probability of second sale) on loss, loss*lumpy mortgage and control variables in Table 4. Standard errors are clustered at the labor-market-area-byquarter level. Panel A reproduces the baseline results from Table 4. Panel B replaces the equity position variable from Panel A with an alternative equity position measure, defined as current LTV truncated at above 0.8. Panel C estimate equation (3) using a linear probability model for sale spells which start from the year after the sale of a property and ends in the year of next sale or the end of our sample period to account for censoring. 
Table 6: Adding Balance Control Interactions

\begin{tabular}{|c|c|c|c|c|}
\hline & G\&M & Lumpy & w/ Gains & $\begin{array}{l}\text { Lumpy w/ } \\
\text { Gains }\end{array}$ \\
\hline & $(1)$ & (2) & (3) & (4) \\
\hline \multicolumn{5}{|l|}{ A. Baseline } \\
\hline Loss & $\begin{array}{l}0.402 * * * \\
(0.011)\end{array}$ & $\begin{array}{l}0.388 * * * \\
(0.017)\end{array}$ & $\begin{array}{l}0.392 * * * \\
(0.012)\end{array}$ & $\begin{array}{l}0.398 * * * \\
(0.018)\end{array}$ \\
\hline Loss*Lumpy Mortgage & & $\begin{array}{l}0.100 * * * \\
(0.020)\end{array}$ & & $\begin{array}{l}0.102 * * * \\
(0.020)\end{array}$ \\
\hline \multicolumn{5}{|c|}{ B. Baseline + balance control interactions } \\
\hline Loss & $\begin{array}{l}0.281 * * * \\
(0.010)\end{array}$ & $\begin{array}{l}0.221 * * * \\
(0.019)\end{array}$ & $\begin{array}{l}0.222 * * * \\
(0.012)\end{array}$ & $\begin{array}{l}0.204 * * * \\
(0.020)\end{array}$ \\
\hline Loss*Lumpy Mortgage & & $\begin{array}{l}0.100 * * * \\
(0.022)\end{array}$ & & $\begin{array}{l}0.108 * * * \\
(0.022)\end{array}$ \\
\hline \multicolumn{5}{|l|}{ C. Probability of Sale } \\
\hline Loss & $\begin{array}{l}-0.005 \\
(0.003)\end{array}$ & $\begin{array}{l}-0.005^{*} \\
(0.003)\end{array}$ & $\begin{array}{l}-0.015^{* *} \\
(0.006)\end{array}$ & $\begin{array}{l}-0.017 * * \\
(0.007)\end{array}$ \\
\hline Loss*Lumpy Mortgage & & $\begin{array}{l}-0.010 * * * \\
(0.002)\end{array}$ & & $\begin{array}{l}-0.007 * * * \\
(0.002)\end{array}$ \\
\hline \multicolumn{5}{|c|}{ D. Probability of Sale + balance controls interactions } \\
\hline Loss & $\begin{array}{l}-0.003 \\
(0.006)\end{array}$ & $\begin{array}{l}0.003 \\
(0.004)\end{array}$ & $\begin{array}{l}-0.021 * * \\
(0.009)\end{array}$ & $\begin{array}{l}-0.015 \\
(0.009)\end{array}$ \\
\hline Loss*Lumpy Mortgage & & $\begin{array}{l}-0.033 * * * \\
(0.005)\end{array}$ & & $\begin{array}{l}-0.030 * * * \\
(0.006)\end{array}$ \\
\hline
\end{tabular}

Notes. Panel A and B (Panels C and D) show results from regressions of sale price (probability of second sale) on loss, loss*lumpy mortgage and control variables in Table 4. Standard errors are clustered at the labor-market-areaby-quarter level. Panel A (Panel C) reproduces the baseline results from Table 4 (Table 5 Panel C). Panels B and D adds all the balance controls for the hedonic, mortgage, and census characteristics (see Table 3 ) and further interact the lumpy mortgage dummy, as well as the LTV focused/subordinate debt dummy, with these variables. 
Table 7: Adding Tract FEs

\begin{tabular}{|c|c|c|c|c|}
\hline & G\&M & Lumpy & w/ Gains & Lumpy w/ Gains \\
\hline & (1) & (2) & $(3)$ & (4) \\
\hline \multicolumn{5}{|l|}{ A. Baseline } \\
\hline Loss & $\begin{array}{l}0.402 * * * \\
(0.011)\end{array}$ & $\begin{array}{l}0.388 * * * \\
(0.017)\end{array}$ & $\begin{array}{l}0.392 * * * \\
(0.012)\end{array}$ & $\begin{array}{l}0.398 * * * \\
(0.018)\end{array}$ \\
\hline Loss*Lumpy Mortgage & & $\begin{array}{l}0.100 * * * \\
(0.020)\end{array}$ & & $\begin{array}{l}0.102 * * * \\
(0.020)\end{array}$ \\
\hline \multicolumn{5}{|c|}{ B. Baseline + tract by type FEs } \\
\hline Loss & $\begin{array}{l}0.275^{* * *} \\
(0.009)\end{array}$ & $\begin{array}{l}0.279 * * * \\
(0.012)\end{array}$ & $\begin{array}{l}0.265^{* * *} \\
(0.009)\end{array}$ & $\begin{array}{l}0.277 * * * \\
(0.013)\end{array}$ \\
\hline Loss*Lumpy Mortgage & & $\begin{array}{l}0.061 * * * \\
(0.016)\end{array}$ & & $\begin{array}{l}0.066^{* * *} \\
(0.016)\end{array}$ \\
\hline \multicolumn{5}{|l|}{ C. Probability of Sale } \\
\hline Loss & $\begin{array}{l}-0.005 \\
(0.003)\end{array}$ & $\begin{array}{l}-0.005^{*} \\
(0.003)\end{array}$ & $\begin{array}{l}-0.015 * * \\
(0.006)\end{array}$ & $\begin{array}{l}-0.017 * * \\
(0.007)\end{array}$ \\
\hline Loss*Lumpy Mortgage & & $\begin{array}{l}-0.010^{* * *} \\
(0.002)\end{array}$ & & $\begin{array}{l}-0.007 * * * \\
(0.002)\end{array}$ \\
\hline \multicolumn{5}{|c|}{ D. Probability of Sale + tract by type FEs } \\
\hline Loss & $\begin{array}{l}-0.007 * \\
(0.004)\end{array}$ & $\begin{array}{l}-0.007 * \\
(0.004)\end{array}$ & $\begin{array}{l}-0.018 * * \\
(0.007)\end{array}$ & $\begin{array}{l}-0.020 * * * \\
(0.007)\end{array}$ \\
\hline Loss*Lumpy Mortgage & & $\begin{array}{l}-0.012 * * * \\
(0.002)\end{array}$ & & $\begin{array}{l}-0.009 * * * \\
(0.002)\end{array}$ \\
\hline
\end{tabular}

Panels A and B (Panels C and D) show results from regressions of sale price (probability of second sale) on loss, loss*lumpy mortgage and control variables in Table 4. Standard errors are clustered at the labor-market-area-byquarter level. Panel A (Panel C) reproduces the baseline results from Table 4 (Table 5 Panel C). Panels B and D adds tract-by-borrower-type fixed effects. 
Table 8: RDD

\begin{tabular}{|c|c|c|}
\hline & Lumpy & Lumpy w/ Gains \\
\hline & (1) & (2) \\
\hline \multicolumn{3}{|l|}{ A. Baseline } \\
\hline \multirow[t]{2}{*}{ Loss } & $0.176 * * *$ & $0.152 * * *$ \\
\hline & $(0.035)$ & $(0.036)$ \\
\hline \multirow[t]{2}{*}{ Loss*Lumpy Mortgage } & $0.103 * * *$ & $0.095 * * *$ \\
\hline & $(0.034)$ & $(0.036)$ \\
\hline \multirow[t]{2}{*}{ Loss*Run } & -0.008 & -0.007 \\
\hline & $(0.025)$ & $(0.025)$ \\
\hline \multirow[t]{2}{*}{ Loss*Run*Above } & 0.007 & 0.010 \\
\hline & $(0.044)$ & $(0.045)$ \\
\hline \multicolumn{3}{|c|}{ B. Baseline + balance control interactions } \\
\hline \multirow[t]{2}{*}{ Loss } & $0.131 * * *$ & $0.149 * * *$ \\
\hline & $(0.032)$ & $(0.034)$ \\
\hline \multirow[t]{2}{*}{ Loss*Lumpy Mortgage } & $0.117 * * *$ & $0.113 * * *$ \\
\hline & $(0.035)$ & $(0.035)$ \\
\hline \multirow[t]{2}{*}{ Loss*Run } & -0.019 & -0.019 \\
\hline & $(0.023)$ & $(0.023)$ \\
\hline \multirow[t]{2}{*}{ Loss*Run*Above } & 0.029 & 0.032 \\
\hline & $(0.039)$ & $(0.039)$ \\
\hline \multicolumn{3}{|c|}{ C. Baseline + tract by type FEs } \\
\hline \multirow[t]{2}{*}{ Loss } & $0.119 * * *$ & $0.109 * * *$ \\
\hline & $(0.025)$ & $(0.026)$ \\
\hline \multirow[t]{2}{*}{ Loss*Lumpy Mortgage } & $0.102 * * *$ & $0.089 * * *$ \\
\hline & $(0.026)$ & $(0.027)$ \\
\hline \multirow[t]{2}{*}{ Loss*Run } & -0.022 & -0.021 \\
\hline & $(0.019)$ & $(0.019)$ \\
\hline \multirow[t]{2}{*}{ Loss*Run*Above } & 0.036 & 0.038 \\
\hline & $(0.032)$ & $(0.032)$ \\
\hline
\end{tabular}

This table summarizes results from regressions of sale price on loss, loss*lumpy mortgage, loss*Run, loss*Run*Above and control variables in Table 4. Run is normalized mortgage amounts around each round number. Above is an indicator variable for Run greater than zero. Standard errors are clustered at the labor-market-area-byquarter level. Panel A shows the baseline results. Panel B adds all the balance controls for the hedonic, mortgage, and census characteristics (see Table 3) and further interact the lumpy mortgage dummy, as well as the LTV focused/subordinate debt dummy, with these variables. Panel $\mathrm{C}$ adds tract-by-borrower-type fixed effects. 
Table 9: Deleting Flippers

\begin{tabular}{|c|c|c|c|c|}
\hline & G\&M & Lumpy & w/ Gains & $\begin{array}{l}\text { Lumpy w/ } \\
\text { Gains }\end{array}$ \\
\hline & $(1)$ & (2) & $(3)$ & $(4)$ \\
\hline \multicolumn{5}{|c|}{ A. Baseline (no flipper as buyer) } \\
\hline Loss & $\begin{array}{l}0.403 * * * \\
(0.011)\end{array}$ & $\begin{array}{l}0.389 * * * \\
(0.017)\end{array}$ & $\begin{array}{l}0.394 * * * \\
(0.012)\end{array}$ & $\begin{array}{l}0.400 * * * \\
(0.018)\end{array}$ \\
\hline Loss*Lumpy Mortgage & & $\begin{array}{l}0.099 * * * \\
(0.020)\end{array}$ & & $\begin{array}{l}0.101 * * * \\
(0.020)\end{array}$ \\
\hline \multicolumn{5}{|c|}{ B. Baseline (no flipper as seller) } \\
\hline Loss & $\begin{array}{l}0.409 * * * \\
(0.011)\end{array}$ & $\begin{array}{l}0.400 * * * \\
(0.017)\end{array}$ & $\begin{array}{l}0.404 * * * \\
(0.012)\end{array}$ & $\begin{array}{l}0.414^{* * *} \\
(0.017)\end{array}$ \\
\hline Loss*Lumpy Mortgage & & $\begin{array}{l}0.090 * * * \\
(0.020)\end{array}$ & & $\begin{array}{l}0.091 * * * \\
(0.020)\end{array}$ \\
\hline \multicolumn{5}{|c|}{ C. Baseline (no flipper as buyer or seller) } \\
\hline Loss & $\begin{array}{l}0.410 * * * \\
(0.011)\end{array}$ & $\begin{array}{l}0.402 * * * \\
(0.016)\end{array}$ & $\begin{array}{l}0.405 * * * \\
(0.012)\end{array}$ & $\begin{array}{l}0.416^{* * *} \\
(0.017)\end{array}$ \\
\hline Loss*Lumpy Mortgage & & $\begin{array}{l}0.089 * * * \\
(0.020)\end{array}$ & & $\begin{array}{l}0.090 * * * \\
(0.020)\end{array}$ \\
\hline \multicolumn{5}{|c|}{ D. Probability of Sale (no flipper as buyer) } \\
\hline Loss & $\begin{array}{l}-0.005 \\
(0.003)\end{array}$ & $\begin{array}{l}-0.005 * \\
(0.003)\end{array}$ & $\begin{array}{l}-0.016 * * \\
(0.006)\end{array}$ & $\begin{array}{l}-0.017 * * * \\
(0.007)\end{array}$ \\
\hline Loss*Lumpy Mortgage & & $\begin{array}{l}-0.010 * * * \\
(0.002)\end{array}$ & & $\begin{array}{l}-0.008 * * * \\
(0.002)\end{array}$ \\
\hline \multicolumn{5}{|c|}{ E. Probability of Sale (no flipper as seller) } \\
\hline Loss & $\begin{array}{l}-0.006^{* *} \\
(0.003)\end{array}$ & $\begin{array}{l}-0.007 * * * \\
(0.003)\end{array}$ & $\begin{array}{l}-0.015^{* *} \\
(0.006)\end{array}$ & $\begin{array}{l}-0.018 * * * \\
(0.007)\end{array}$ \\
\hline Loss*Lumpy Mortgage & & $\begin{array}{l}-0.008 * * * \\
(0.002)\end{array}$ & & $\begin{array}{l}-0.006^{* * * *} \\
(0.002)\end{array}$ \\
\hline \multicolumn{5}{|c|}{ F. Probability of Sale (no flipper as buyer or seller) } \\
\hline Loss & $\begin{array}{l}-0.006 * * \\
(0.003)\end{array}$ & $\begin{array}{l}-0.007 * * * \\
(0.003)\end{array}$ & $\begin{array}{l}-0.016 * * \\
(0.006)\end{array}$ & $\begin{array}{l}-0.018 * * * \\
(0.007)\end{array}$ \\
\hline Loss*Lumpy Mortgage & & $\begin{array}{l}-0.009 * * * \\
(0.002)\end{array}$ & & $\begin{array}{l}-0.006^{* * *} \\
(0.002)\end{array}$ \\
\hline
\end{tabular}

This table summarizes results deleting flippers. Panels A, B and C (Panels C, D, and F) show results from regressions of sale price (probability of second sale) on loss, loss*lumpy mortgage and control variables in Table 4. Standard errors are clustered at the labor-market-area-by-quarter level. Panels A and D show results deleting flippers as the buyer in the first sale. Panels B and E show results deleting flippers as the seller in the second sale. Panels $\mathrm{C}$ and $\mathrm{F}$ show results deleting flippers as either the buyer or the seller. 
Table 10: Holding period

\begin{tabular}{|c|c|c|c|c|}
\hline & $\begin{array}{l}\text { G\&M } \\
\text { (1) }\end{array}$ & $\begin{array}{l}\text { Lumpy } \\
\text { (2) }\end{array}$ & $\begin{array}{l}\text { w/ Gains } \\
\text { (3) }\end{array}$ & $\begin{array}{l}\text { Lumpy w/ Gains } \\
\text { (4) }\end{array}$ \\
\hline \multicolumn{5}{|c|}{ A. Baseline (below median) } \\
\hline Loss & $\begin{array}{l}0.465 * * * \\
(0.017)\end{array}$ & $\begin{array}{l}0.399 * * * \\
(0.028)\end{array}$ & $\begin{array}{l}0.501 * * * \\
(0.019)\end{array}$ & $\begin{array}{l}0.450 * * * \\
(0.030)\end{array}$ \\
\hline Loss*Lumpy Mortgage & & $\begin{array}{l}0.210^{* * *} \\
(0.035)\end{array}$ & & $\begin{array}{l}0.217 * * * \\
(0.037)\end{array}$ \\
\hline \multicolumn{5}{|c|}{ B. Baseline (above median) } \\
\hline Loss & $\begin{array}{l}0.473 * * * \\
(0.014)\end{array}$ & $\begin{array}{l}0.453 * * * \\
(0.019)\end{array}$ & $\begin{array}{l}0.542 * * * \\
(0.014)\end{array}$ & $\begin{array}{l}0.535 * * * \\
(0.019)\end{array}$ \\
\hline Loss*Lumpy Mortgage & & $\begin{array}{l}0.021 \\
(0.024)\end{array}$ & & $\begin{array}{l}-0.004 \\
(0.023)\end{array}$ \\
\hline \multicolumn{5}{|c|}{ C. Probability of Sale (below median) } \\
\hline Loss & $\begin{array}{l}0.003 \\
(0.005)\end{array}$ & $\begin{array}{l}0.006 \\
(0.004)\end{array}$ & $\begin{array}{l}-0.049 * * * \\
(0.012)\end{array}$ & $\begin{array}{l}-0.047 * * * \\
(0.013)\end{array}$ \\
\hline Loss*Lumpy Mortgage & & $\begin{array}{l}-0.015^{* * *} \\
(0.004)\end{array}$ & & $\begin{array}{l}-0.007 * \\
(0.004)\end{array}$ \\
\hline \multicolumn{5}{|c|}{ D. Probability of Sale (above median) } \\
\hline Loss & $\begin{array}{l}-0.023 * * * \\
(0.004)\end{array}$ & $\begin{array}{l}-0.025^{* * *} \\
(0.004)\end{array}$ & $\begin{array}{l}-0.079 * * * \\
(0.019)\end{array}$ & $\begin{array}{l}-0.084 * * * \\
(0.019)\end{array}$ \\
\hline Loss*Lumpy Mortgage & & $\begin{array}{l}-0.006^{* *} \\
(0.003)\end{array}$ & & $\begin{array}{l}-0.004 \\
(0.003)\end{array}$ \\
\hline
\end{tabular}

This table summarizes results deleting flippers. Panels A, B and C (Panels C, D, and F) show results from regressions of sale price (probability of second sale) on loss, loss*lumpy mortgage and control variables in Table 4. Standard errors are clustered at the labor-market-area-by-quarter level. Panels A (Panel C) shows results based on observations with months since purchase (year since purchase) below median. Panels B (Panel D) shows results based on observations with months since purchase (year since purchase) above med 


\section{Appendix 1: Variable Definitions}

\begin{tabular}{|c|c|}
\hline Variable & Definition \\
\hline Sale price & Log of sale price of the second sale. \\
\hline Sale probability & An indicator variable if house $i$ was sold in year $t$. \\
\hline Lumpy mortgage & $\begin{array}{l}\text { An indicator variable if } 1 \text { st mortgage amount at purchase with } 0 \text { or } 5 \text { on } 000 \text { ' and LTV } \\
\text { focused dummy equals zero. }\end{array}$ \\
\hline LTV focused & $\begin{array}{l}\text { An indicator variable if the LTV ratio at purchase equals one of the critical ratios, e.g., } \\
0.80,0.90,0.95,0.97 \text {, and } 1.00 \text {, that suggest that the buyer targeted an important LTV } \\
\text { ratio in the market) or took out a second mortgage at the time of purchase (subordinate } \\
\text { debt). Appendix } 2 \text { summarizes details on identifying critical LTV ratios. }\end{array}$ \\
\hline Loss & $\begin{array}{l}\text { Difference between the first sale price and the expected price truncated above at zero. } \\
\text { It is measured at the time of second sale (year } t \text { within a sale spell) in repeat sale } \\
\text { analysis (panel data analysis) for sale price (sale probability) as the outcome variable. }\end{array}$ \\
\hline Gain & $\begin{array}{l}\text { Difference between the first sale price and the expected price truncated below at zero. } \\
\text { It is measured at the time of second sale (year } t \text { within a sale spell) in repeat sale } \\
\text { analysis (panel data analysis) for sale price (sale probability) as the outcome variable. }\end{array}$ \\
\hline Equity Position & $\begin{array}{l}\text { Equity position of the loan assuming a } 30 \text {-year mortgage amortized using the } 30 \text {-year } \\
\text { mortgage interest rate at purchase. It is measured at the time of second sale (year } t \\
\text { within a sale spell) in repeat sale analysis (panel data analysis) for sale price (sale } \\
\text { probability) as the outcome variable. An alternative equity position is measured as } \\
\text { equity position truncated at above } 0.8 \text {. }\end{array}$ \\
\hline Expected price & Predicted value estimated by the hedonic model \\
\hline First residual & The residual from the hedonic regression for the first sale \\
\hline Month & $\begin{array}{l}\text { Number of months between the first and second sale ysed in repeat sale analysis for } \\
\text { sale price as the outcome variable }\end{array}$ \\
\hline Years since last sale & $\begin{array}{l}\text { Number of years since purchase used in panel data analysis for sale probability as the } \\
\text { outcome variable }\end{array}$ \\
\hline
\end{tabular}

Housing Characteristic

Interior size

Lot size

2-3 bathrooms

$>3$ bathrooms

Age

\section{Mortgage attributes}

Mortgage amount

Combined mortgage amount

LTV ratio

CLTV ratio

Presence of second mortgage
Interior size (sq. ft.) of the house

Lot size (sq. ft.) of the house

An indicator variable if 2-3 bathrooms

An indicator variable if $>3$ bathrooms

Age of the house

Log of $1^{\text {st }}$ mortgage amount (taken from the first sale)

Log of combined mortgage amount (taken from the first sale)

Loan-to-value ratio (taken from the first sale)

Combined loan-to-value ratio (taken from the first sale)

An indicator variable if there is a second mortgage in the first sale

\section{Census block characteristics (Census 1990)}

Percent female

Percent white

Median income

Percent with college education

Percent of households with kids

Average household size

Percent below poverty

Percent of owner-occupied

housing with mortgage

Unemployment rate

Vacancy rate

Median value of owner-occupied

housing

Percent of 65 and over
Percent of female population

Percent of white population

Median Household Income (in 2000 Dollars)

Percent of population with college degree

Percent of married-couple families

Average household size

Percent of households below poverty level

Percent of owner-occupied houses with mortgage

Unemployment rate

Percentage of vacant housing units

Median value of owner-occupied housing (in 2000 Dollars)

Percent of age 65 and over 


\section{Appendix 2: Identifying Critical LTV Thresholds}

Given the complexities of the mortgage market, we use a data driven approach to establishing LTV ratios associated with borrowers attempting to hit critical thresholds within the mortgage market. We start with the standard critical LTVs, including $0.8,0.9,0.95,0.97,1.00$. As one never gets exactly 0.8 . The exact LTV is something like 0.800001. We follow Pope et al. (2015), round down LTVs into 3-digit bin, and define the critical LTV thresholds using these bins. For example, 0.7912 will be round to 0.791.

In addition to the standard LTVs, we run histograms of number of loans at different LTV percentage points (e.g., $0.80<=\mathrm{LTV}<0.81$ ) to check actual spikes. For example, we observe huge spikes at 0.95 due to conforming loan limit with PMI and at 0.97 due to the FHA limit. Specifically, we perform checks for: (A) every 0.001 from 0.780 to 0.820 , from 0.880 to 0.920 and 0.930 to 0.960 for the entire sample; (B) every 0.001 from 0.960 to 1.010 by splitting the sample into three parts: (1) start to Q32008, (2) Q42008 to Q42014, and (3) Q12015 to the end of the sample.

After checking the spikes in the histogram (unreported), we identify the following critical LTVs:

- $\quad 0.799,0.800,0.899,0.900,0.949,0.950$ for the entire sample,

- $\quad 0.969,0.970,0.983,0.984,0.991,0.992,0.999,1.000$ before 2009,

- $0.974,0.981,0.986,1.000$ from 2009 to 2014 , and

- $\quad 0.970,0.981,1.000$ from 2015 to the end of sample.

Although these spikes vary over the sample period and some do not fall right at integers, these critical LTVs can be justified. For example, Fannie Mae had a smaller Flex 97 program launched after 2008. The fact that post-2008 FHFA increased their loan requirements from 3 to 3.5 percen explains the mortgage spike at 0.974 . The 0.986 might be some additional mortgages that were made at $0.97-$ there were some exceptions to the 0.965 . We justify spikes at 0.981 and 0.984 (just over 0.98 ) as the borrowers could roll the upfront mortgage insurance premium into the mortgage amount. Spikes at 0.991 are because prior to 2008 there were quite a few non-governmental mortgages right at 0.99 .

We defined constrained borrower based on LTV thresholds, instead of CLTV thresholds. This is because having a second mortgage usually involves a credit constraint, we lump people who have a second mortgage together with people who hit a specific LTV threshold. Nevertheless, our results do not change if we use CLTV because there is only a small fraction of borrowers with a second mortgage. 